\title{
Characterization of vegetative and reproductive tillers as a basis to recommend heights and nitrogen doses for the stockpillage of Marandu palisade grass
}

Received: Jun 2020; Accepted: Aug 2020

\author{
Gabriel de Oliveira Rocha, Bruno Humberto Rezende Carvalho, \\ Davi Moraes de Oliveira, Lucas Dias de Moraes, \\ Manoel Eduardo Rozalino Santos ${ }^{1^{*}}$
}

\begin{abstract}
This article aims to determine the adequate pasture height and the nitrogen dose at the beginning of the deferral period for Urochloa brizantha cv. Marandu (Marandu palisade grass). Two pasture heights (15 and $30 \mathrm{~cm})$ and four nitrogen doses $\left(0,40,80\right.$, and $\left.120 \mathrm{~kg} \mathrm{ha}^{-1}\right)$ were evaluated in a completely randomized factorial $(4 \times 2)$ design with three replications. A linear increase in the number of vegetative tillers was observed with the application of nitrogen in the $15-\mathrm{cm}$ deferred pasture. The lengths of stem and leaf blades of tillers increased linearly with the application of nitrogen. The weight of the vegetative tillers was greater in the $30-\mathrm{cm}$ deferred pasture, compared to the $15-\mathrm{cm}$ one when the pasture was fertilized with 0 and $40 \mathrm{~kg} \mathrm{ha}^{-1}$ of $\mathrm{N}$. The nitrogen fertilization linearly increased the weight of both the vegetative tillers in the $15-\mathrm{cm}$ deferred pastures and the reproductive tillers in the $30-\mathrm{cm}$ deferred pastures. The recommendation is that Marandu palisade grass be deferred with $15 \mathrm{~cm}$ and fertilized with $80 \mathrm{~kg}$ ha- 1 of $\mathrm{N}$ at the beginning of the deferment period.
\end{abstract}

Keywords: Fertilization, Population Density, Structure, Urochloa brizantha, Deferment period.

\section{Introduction}

Nitrogen fertilization in stockpiled pastures allows not only for maintaining the sustainability of the productive system through nutrient reposition, but also for increasing forage production in the winter (AMORIM et al., 2019).

\footnotetext{
${ }^{1}$ Faculdade de Medicina Veterinária da Universidade Federal de Uberlândia, Uberlândia-MG.

* Corresponding author: manoel.rozalino@ufu.br Universidade Federal de Uberlândia, Faculdade de Medicina Veterinária. (34) 25126813
} 
Reducing the height of the pasture before the start of the stockpiling period is also recommended to provide removal of old forage from the pasture and, in effect, to ensure a greater incidence of light at the base of the plants, which stimulates the development of basal buds in new vegetative tillers (SOUZA et al., 2012). Consequently, a stockpiled pasture is produced with a better structure and nutritional value, potentially resulting in improved animal consumption and performance in the winter.

Variations in the fertilizer dose and the height of the pasture used at the beginning of the stockpiling period promote changes in the number and morphological characteristics of the tillers, which are the growth units of the pasture (SANTOS et al., 2020). Eventually, identifying the tiller population density and the morphological characterization of the tiller classes in stockpiled pastures provides for management strategies that result in a deferred pasture with better characteristics for animal production.

This paper reports on an experiment aimed to determine the appropriate height and nitrogen level dose at the beginning of the stockpiling period for Urochloa brizantha cv. Marandu.

\section{Material and methods}

The experiment was carried out in a $150-\mathrm{m}^{2}$ pasture area with Urochloa brizantha cv. Marandu (marandu palisade grass) at Capim Branco Farm, Federal University of Uberlândia, Uberlândia, Minas Gerais (18 $30^{\circ}$ $\mathrm{S} ; 47^{\circ} 50^{\prime} \mathrm{W} ; 863 \mathrm{~m}$ absl), from March 15 to June 15, 2012. According to the Köppen classification, the climate is Aw, tropical savanna (ALVARES et al., 2013), with well-defined dry and rainy seasons. Climatic conditions were monitored during the experiment (Table 1).

The soil in the experimental area was classified as Oxisol. Soil analysis carried out at the beginning of March 2012, in the 0 to $20 \mathrm{~cm}$ deep layer, provided the following results: $\mathrm{pH}\left(\mathrm{H}_{2} \mathrm{O}\right): 6.1 ; \mathrm{P}$ (Mehlich-1): 2.5; $\mathrm{K}^{+}$ 
Rocha, Carvalho, Oliveira, Moraes, Santos Characterization of vegetative and reproductive tillerss...

$\left(\mathrm{KCl} 1 \mathrm{~mol} \mathrm{~L}^{-1}\right): 366 \mathrm{mg} \mathrm{dm}{ }^{-3} ; \mathrm{Ca}^{2+}\left(\mathrm{KCl} 1 \mathrm{~mol} \mathrm{~L}^{-1}\right): 3.1 ; \mathrm{Mg}^{2+}\left(\mathrm{KCl} 1 \mathrm{~mol} \mathrm{~L}^{-1}\right)$ : 1,3; $\mathrm{Al}^{3+}\left(\mathrm{KCl} 1 \mathrm{~mol} \mathrm{~L}^{-1}\right): 0.0 \mathrm{cmolc} \mathrm{dm}^{-3}$; organic matter (colorimetric method): 4.9 dag $\mathrm{kg}^{-1}$; sum od bases (SB): 5.3; base saturation (V): $62 \%$.

Table 1. Monthly average of daily average temperature, solar radiation, monthly precipitation, and evapotranspiration as obtained in a meteorological station located approximately $200 \mathrm{~m}$ from the experimental area from March to June 2012

\begin{tabular}{ccccc}
\hline Month & $\begin{array}{c}\text { Mean daily temperature } \\
\text { air }\left({ }^{\circ} \mathrm{C}\right)\end{array}$ & $\begin{array}{c}\text { Solar radiation } \\
\left(\mathrm{Mj}^{\prime} / \mathrm{day}^{-1}\right)\end{array}$ & Rainfall $(\mathrm{mm})$ & $\begin{array}{c}\text { Evapotranspiratio } \\
(\mathrm{mm})\end{array}$ \\
\hline March & 22.8 & 18.1 & 143.2 & 88.7 \\
April & 22.3 & 15.7 & 47.6 & 79.5 \\
May & 19.9 & 10.6 & 10 & 54.3 \\
June & 19.9 & 14.9 & 29.2 & 71.1 \\
\hline
\end{tabular}

Two pasture heights (15 and $30 \mathrm{~cm})$ and four nitrogen doses $(0,40,80$, and $120 \mathrm{~kg} \mathrm{ha}^{-1}$ ) were evaluated at the beginning of the stockpiling period of Marandu grass. Urea was used as a nitrogen source and applied manually in a single dose on the pasture surface in the late afternoon. The experimental design was completely randomized, with three replications and a $4 \times 2$ factorial scheme. The plot area was $6 \mathrm{~m}^{2}$.

The stockpiling period occurred from March 15 to June 15, 2012 (93 days). At the beginning of this period, the heights of the pastures were adjusted by cutting with a brush cutter. All assessments were carried out after the stockpiling period.

The number of tillers was determined by taking two samples in the useful area of each plot. For sampling, a rectangle made of 25 x 50-cm rebar was used, and all tillers inside this rectangle were harvested, cut at the soil surface level, and separated into reproductive (with visible inflorescence) and vegetative (without visible inflorescence).

Samples consisting of 30 vegetative tillers and 30 reproductive tillers were collected at random from each plot. These tillers had their live leaf blades separated. Together with the rest of the samples, this morphological 
component was dried in a forced ventilation oven at $65{ }^{\circ} \mathrm{C}$ for 72 hours and weighed thereafter. It was used for calculating the mass of live leaf of the tiller and the unit weight of each category of tillers.

To determine the tiller leaf area, 40 leaf blades were harvested at random in each plot. They were cut at the ends so that they were rectangular in shape. Subsequently, the length and width of each were measured to estimate its area. The leaf blades were then dried in a forced ventilation oven at $65{ }^{\circ} \mathrm{C}$ for 72 hours and then weighed. This was used for calculating the specific leaf area (SLA, $\mathrm{cm}^{2} \mathrm{mg}^{-1}$ ). The leaf area of each tiller was obtained by multiplying the mass of the live leaf blade of the tiller by the SLA.

In ten tillers of each category per plot, measurements were made for the lengths of the pseudostem and leaf blade, as well as for the numbers of live and dead leaves. The length of the pseudostem was measured from the ground level to the younger expanded leaf. The leaf blade length corresponded to the distance from the apex of the expanded leaves to its ligula. Expanding and expanded leaves were considered to be alive; those that had more than $50 \%$ of the senescent leaf blade were considered to be dead.

The numbers of reproductive tillers were analyzed descriptively only, due to data variability, with several values equal to zero. For the other variables, statistical analyzes were carried out at the level of $5 \%$ probability of occurrence of type I error. For the nitrogen dose, regression analyses were performed with a selection of models that best fit the data within each height pasture assessed. The largest response surface model in the averages of the nitrogen dose factor was as follows:

$\mathrm{Yi}=\mathrm{B0}+B 1 \mathrm{Ni}+82 \mathrm{Ni}^{2}+\mathrm{ei}$

where: $\mathrm{Yi}=$ response variable; $\mathrm{Ni}=$ nitrogen dose; $\mathrm{B0}, \mathrm{B1}, \mathrm{B2}=$ parameters to be estimated; ei $=$ experimental error. The degree of adjustment of the models was assessed by the coefficient of determination 
Rocha, Carvalho, Oliveira, Moraes, Santos Characterization of vegetative and reproductive tillerss...

and the significance of the regression coefficients was tested by the corrected t-test based on the residuals of the analysis of variance. For height (qualitative factor), a t-test was applied across the four doses of nitrogen.

\section{Results and Discussion}

There was a linear and positive effect $(\mathrm{P}<0,0001)$ of $\mathrm{N}$ doses on the number of vegetative tillers in the $15-\mathrm{cm}$ deferred pasture (Table 2). However, there was no effect $(\mathrm{P}<0.05)$ of nitrogen on the population of vegetative tillers for the 30 -cm deferred pasture.

Table 2. Density of vegetative and reproductive tillers in Marandu grass pastures managed with varying heights and nitrogen doses at the beginning of the stockpiling period

\begin{tabular}{|c|c|c|c|c|c|c|}
\hline \multirow{2}{*}{ Height (cm) } & \multicolumn{4}{|c|}{ Nitrogen Dose $\left(\mathrm{kg} \mathrm{ha}^{-1}\right)$} & \multirow{2}{*}{ Equation } & \multirow{2}{*}{$\mathrm{R}^{2}$} \\
\hline & 0 & 40 & 80 & 120 & & \\
\hline & \multicolumn{6}{|c|}{ Vegetative Tiller $\mathrm{m}^{-2}$} \\
\hline 15 & $604 a$ & $665 a$ & $632 \mathrm{a}$ & $736 \mathrm{a}$ & $\hat{\mathrm{Y}}=604.9333+0.9067^{*} \mathrm{~N}$ & 0.68 \\
\hline 30 & $568 \mathrm{a}$ & $575 a$ & $573 a$ & $491 \mathrm{~b}$ & $\hat{\mathrm{Y}}=552$ & - \\
\hline & \multicolumn{6}{|c|}{ Reproductive Tiller $\mathrm{m}^{-2}$} \\
\hline 15 & 9 & 24 & 30 & 44 & $\hat{\mathrm{Y}}=27$ & - \\
\hline 30 & 51 & 59 & 41 & 47 & $\hat{\mathrm{Y}}=50$ & - \\
\hline
\end{tabular}

For each characteristic, means followed by the same letter in the column do not differ $(\mathrm{P}>0,10)$ by the t-test; * Significant by t-test $(\mathrm{P}<0,05) .{ }^{(1)}$ Descriptive data.

When the leaf area index (LAI) of the pasture is low, as in the one stockpiled with less height $(15 \mathrm{~cm}), \mathrm{N}$ produces a positive effect on the filling site, stimulating tillering (PACIULLO et al., 2016). The filling site is characterized by the development of existing axillary gems in new tillers (SKINNER \& NELSON, 1995). Thus, lowering the grass to $15 \mathrm{~cm}$ favored the incidence of light at the base of the plants, which stimulated the appearance of vegetative tillers with the application of $\mathrm{N}$.

When the pasture reaches the critical LAI, that is, when the canopy intercepts $95 \%$ of the incident light, tillering is inhibited (SBRISSIA \& SILVA, 2008). This situation probably occurred with the 30-cm stockpiled Marandu grass, as the Marandu grass canopy intercepts 95\% of the incident 
light at a height of approximately $25 \mathrm{~cm}$. Under this condition, there is the shading and death of several smaller vegetative tillers due to the competition for light (SBRISSIA \& SILVA, 2008).

In stockpiled pasture with a higher initial height $(30 \mathrm{~cm})$, the environment inside the canopy is generally more shaded (SOUZA et al., 2012). This shading is greater when the tallest pasture is fertilized with a high dose of $\mathrm{N}\left(120 \mathrm{~kg} \mathrm{ha}^{-1}\right)$ because, in this situation, the tillers have a higher growth rate (PEREIRA et al., 2015). As a result, tillering is inhibited, which is why there was a lower number of vegetative tillers in the high Marandu grass pasture as compared to the low one when the high dose of $\mathrm{N}$ was applied (Table 2).

There was no effect $(\mathrm{P}=0.1401)$ of nitrogen fertilization on the number of reproductive tillers in stockpiled pastures with 15 or $30 \mathrm{~cm}$ (Table 2). However, lowering the Marandu grass to $15 \mathrm{~cm}$ resulted $(\mathrm{P}=0.0075)$ in a lower number of reproductive tillers in the deferred pasture, mainly when lower doses of $\mathrm{N}$ were applied (Table 2). Possibly, most of the tillers meristems were eliminated because of the most intense cut $(15 \mathrm{~cm})$. This probably resulted in the mortality of the older tillers and those whose apical meristems were eliminated, as well as in the regrowth of younger tillers, which remained in the vegetative stage during the stockpiling period. An opposite response pattern may have occurred when the pastures were $30 \mathrm{~cm}$ apart.

The vegetative tillers had greater relative share in the stockpiled pastures (on average, 94\% of the total tillers). Thus, variation in the characteristics of the vegetative tillers is supposed to determine greater effects in the structural characteristics of the deferred pastures.

The stem length in vegetative $(\mathrm{P}=0,0009)$ and reproductive $(\mathrm{P}=0,0302)$ tillers increased linearly with the application of nitrogen in stockpiled pastures with an initial height of 15 and $30 \mathrm{~cm}$ (Tables 3 and 4). The greater growth of forage grass fertilized with $\mathrm{N}$ (PEREIRA et al., 2015) results in a 
Rocha, Carvalho, Oliveira, Moraes, Santos Characterization of vegetative and reproductive tillerss...

higher pasture, a condition under which competition for light inside the canopy is intense and which contributes to the greater length of the stem and to placing the youngest leaves in the upper stratum of the pasture, where brightness is greater.

In general, the length of the stem was greater $(\mathrm{P}=0,0011)$ in stockpiled pastures with greater initial height (Tables 3 and 4). Probably, the LAI was at or above the critical LAI in the $30 \mathrm{~cm}$ stockpiled pastures, as already discussed. Under this condition, the elongation of the stem is enhanced due to the greater competition for light inside the canopy.

In general, the leaf blade lengths of vegetative $(\mathrm{P}<0,0001)$ and reproductive $(\mathrm{P}=0,0016)$ tillers increased with nitrogen fertilization in stockpiled pastures with an initial height of 15 and $30 \mathrm{~cm}$ (Tables 3 and 4). Nitrogen has a positive effect on the rate of cell division found in the leaf elongation zone (SKINNER \& NELSON, 1995) and accelerates the process of producing new tissues (PEREIRA et al., 2015).

Table 3. Structural characteristics of vegetative tillers in Marandu grass pastures managed with varying heights and nitrogen doses at the beginning of the stockpiling period

\begin{tabular}{|c|c|c|c|c|c|c|}
\hline \multirow{2}{*}{ Heights (cm) } & \multicolumn{4}{|c|}{ Nitrogen Dose } & \multirow{2}{*}{ Equation } & \multirow{2}{*}{$\mathrm{R}^{2}$} \\
\hline & 0 & 40 & 80 & 120 & & \\
\hline \multicolumn{7}{|c|}{ Stem length $(\mathrm{cm})$} \\
\hline 15 & $10,4 b$ & $14.0 \mathrm{~b}$ & $17.8 \mathrm{~b}$ & $23.7 \mathrm{~b}$ & $\hat{\mathrm{Y}}=9.9013+0.1095^{*} \mathrm{~N}$ & 0.98 \\
\hline 30 & $19.1 \mathrm{a}$ & $25.1 \mathrm{a}$ & $22.2 \mathrm{a}$ & $31.2 \mathrm{a}$ & $\hat{\mathrm{Y}}=19.361+0.0835^{*} \mathrm{~N}$ & 0.70 \\
\hline \multicolumn{7}{|c|}{ Leaf blade length (cm) } \\
\hline 15 & $16.7 \mathrm{~b}$ & $22.4 \mathrm{~b}$ & $25.2 \mathrm{a}$ & $25.8 \mathrm{~b}$ & $\hat{\mathrm{Y}}=17.99+0.0757 * \mathrm{~N}$ & 0.88 \\
\hline 30 & $21.8 \mathrm{a}$ & $29.0 \mathrm{a}$ & $25.1 \mathrm{a}$ & $34.3 \mathrm{a}$ & $\hat{\mathrm{Y}}=22.48+0.0841 * \mathrm{~N}$ & 0.65 \\
\hline \multicolumn{7}{|c|}{ Number of live leaves } \\
\hline 15 & $4.5 \mathrm{a}$ & $4.0 \mathrm{a}$ & $4.4 \mathrm{a}$ & $4.0 \mathrm{a}$ & $\hat{\mathrm{Y}}=4.2$ & - \\
\hline 30 & $4.4 \mathrm{a}$ & $4.3 \mathrm{a}$ & $3.9 \mathrm{a}$ & $4.0 \mathrm{a}$ & $\hat{\mathrm{Y}}=4.4067-0.004^{*} \mathrm{~N}$ & 0.78 \\
\hline \multicolumn{7}{|c|}{ Number of dead leaves } \\
\hline 15 & $2.1 \mathrm{a}$ & $2.5 \mathrm{a}$ & $2.4 \mathrm{a}$ & $2.3 \mathrm{a}$ & $\hat{\mathrm{Y}}=2.3$ & - \\
\hline 30 & $1.9 \mathrm{a}$ & $2.5 \mathrm{a}$ & $2.7 \mathrm{a}$ & $2.7 \mathrm{a}$ & $\hat{\mathrm{Y}}=2.0633+0.0062 * \mathrm{~N}$ & 0.77 \\
\hline
\end{tabular}

For each characteristic, means followed by the same letter in the column do not differ $(\mathrm{P}>0.10)$ by the t-test; * Significant by t-test $(\mathrm{P}<0.05)$. 
Stockpiled pastures with higher initial height may have tiller with longer leaf blades due to the longer stem length (Table 3). In longer tillers, the expanding leaf travels the longest path between its connection point with the meristematic region and the tip of the pseudostem and, consequently, the leaf elongation time is longer, which results in longer leaf blades (SKINNER \& NELSON, 1995).

Nitrogen fertilization did not affect the number of live leaves in the 15 $\mathrm{cm}$ deferred pasture, both for vegetative tillers (Table 3) and for reproductive tillers (Table 4$)$. There were also no differences $(\mathrm{P}>0,05)$ for the number of dead tiller leaves between 15 and $30-\mathrm{cm}$ deferred pastures (Tables 3 and 4).

Table 4. Structural characteristics of reproductive tillers in Marandu grass pastures managed with varying heights and nitrogen doses at the beginning of the stockpiling period

\begin{tabular}{|c|c|c|c|c|c|c|}
\hline \multirow{2}{*}{ Height $(\mathrm{cm})$} & \multicolumn{4}{|c|}{ Nitrogen dose $\left(\mathrm{kg} \mathrm{ha}^{-1}\right)$} & \multirow{2}{*}{ Equation } & \multirow{2}{*}{$\mathrm{R}^{2}$} \\
\hline & 0 & 40 & 80 & 120 & & \\
\hline \multicolumn{7}{|c|}{ Stem length $(\mathrm{cm})$} \\
\hline 15 & $31.2 \mathrm{~b}$ & $36.0 \mathrm{~b}$ & $46.4 \mathrm{a}$ & $50.1 \mathrm{~b}$ & $\hat{\mathrm{Y}}=30.909+0.1671^{*} \mathrm{~N}$ & 0.97 \\
\hline 30 & $45.2 \mathrm{a}$ & $46.2 \mathrm{a}$ & $49.0 \mathrm{a}$ & $67.7 \mathrm{a}$ & $\hat{\mathrm{Y}}=41.516+0.1751^{*} \mathrm{~N}$ & 0.74 \\
\hline \multicolumn{7}{|c|}{ Leaf blade length $(\mathrm{cm})$} \\
\hline 15 & $9.7 \mathrm{~b}$ & $13.3 \mathrm{a}$ & $14.1 \mathrm{a}$ & $11.4 \mathrm{~b}$ & $\hat{\mathrm{Y}}=9.7121+0.1303^{*} \mathrm{~N}-0.001 * \mathrm{~N}^{2}$ & 0.99 \\
\hline 30 & $11.8 \mathrm{a}$ & $13.4 \mathrm{a}$ & $13.6 \mathrm{a}$ & $16.7 \mathrm{a}$ & $\hat{\mathrm{Y}}=11.637+0.0369 * \mathrm{~N}$ & 0.88 \\
\hline \multicolumn{7}{|c|}{ Number of live leaves } \\
\hline 15 & $3.7 \mathrm{a}$ & $3.8 \mathrm{a}$ & $3.4 \mathrm{a}$ & $3.7 \mathrm{a}$ & $\hat{\mathrm{Y}}=3.7$ & - \\
\hline 30 & $3.6 \mathrm{a}$ & $3.5 \mathrm{a}$ & $3.1 \mathrm{a}$ & $3.7 \mathrm{a}$ & $\hat{\mathrm{Y}}=3.535-0.0237 * \mathrm{~N}+0.0002 * \mathrm{~N}^{2}$ & 0.96 \\
\hline \multicolumn{7}{|c|}{ Number of dead leaves } \\
\hline 15 & $4.4 \mathrm{a}$ & $5.1 \mathrm{a}$ & $4.9 \mathrm{a}$ & $5.3 \mathrm{a}$ & $\hat{\mathrm{Y}}=4.56+0.0061 * \mathrm{~N}$ & 0.64 \\
\hline 30 & $5.3 \mathrm{a}$ & $5.6 \mathrm{a}$ & $5.6 \mathrm{a}$ & $5.4 \mathrm{a}$ & $\hat{\mathrm{Y}}=5.5$ & - \\
\hline
\end{tabular}

For each characteristic, means followed by the same letter in the column do not differ $(\mathrm{P}>0.10)$ by the t-test; * Significant by t-test $(\mathrm{P}<0.05)$.

The number of live leaves per vegetative tiller in the $30 \mathrm{~cm}$ stockpiled pasture decreased linearly $(\mathrm{P}<0,0001)$ with the $\mathrm{N}$ dose (Table 3). The reduction in leaf life with nitrogen fertilization can be explained by the greater tissue renewal in plants (PEREIRA et al., 2011). 
For vegetative tillers, there was no effect $(\mathrm{P}=0,1513)$ of $\mathrm{N}$ fertilization on the number of dead leaves per tiller in 15-cm stockpiled pasture, but there was a linear increase in this characteristic $(\mathrm{P}<0,0001)$ when the pasture was stockpiled to $30 \mathrm{~cm}$ (Table 3). For the reproductive tillers, there was no effect $(\mathrm{P}>0,2108)$ of nitrogen on the number of dead leaves in the 30 $\mathrm{cm}$ deferred pasture $(\mathrm{P}>0.05)$, but there was a linear increase of this characteristic $(\mathrm{P}=0,0033)$ when the pasture was deferred by $15 \mathrm{~cm}$ (Table 4$)$.

The increments in the number of dead leaves, as well as the decrease in the number of live leaves of tillers due to nitrogen fertilization can be justified by the greater shading of tillers in these fertilized canopies.

In the $30 \mathrm{~cm}$ stockpiled pastures, the vegetative $(\mathrm{P}<0,0001)$ and reproductive $(\mathrm{P}=0,0109)$ tillers had an increased linear effect of the leaf area with nitrogen fertilization (Table 5). The positive linear effect observed for the leaf area of vegetative and reproductive tillers is related to the length of the leaf blade, which increased with nitrogen fertilization in the $30-\mathrm{cm}$ deferred pasture tillers (Tables 3 and 4).

A quadratic effect was observed in the $15-\mathrm{cm}$ stockpiled pasture of both types of tillers, i.e, the leaf area of both vegetative and reproductive tillers was positively influenced by nitrogen fertilization to a certain point, after which nitrogen started to have a negative effect on the tillers area. This may have occurred because higher doses of nitrogen accelerate the rate of leaf senescence (PEREIRA et al., 2011), given the more shaded environment inside fertilized and more developed canopies.

Table 5. Leaf area of vegetative and reproductive tillers in Marandu grass pastures managed with varying heights and nitrogen doses at the beginning of the stockpiling period

\begin{tabular}{|c|c|c|c|c|c|c|}
\hline \multirow{2}{*}{ Height (cm) } & \multicolumn{4}{|c|}{ Nitrogen dose $\left(\mathrm{kg} \mathrm{ha}^{-1}\right)$} & \multirow{2}{*}{ Equation } & \multirow{2}{*}{$\mathrm{R}^{2}$} \\
\hline & 0 & 40 & 80 & 120 & & \\
\hline \multicolumn{7}{|c|}{ Vegetative tiller $\left(\mathrm{cm}^{2}\right)$} \\
\hline 15 & $65 a$ & $86 a$ & $97 \mathrm{a}$ & $82 \mathrm{a}$ & $\hat{\mathrm{Y}}=64.567+0.818^{*} \mathrm{~N}-0.0056^{*} \mathrm{~N}^{2}$ & 0.97 \\
\hline 30 & $75 \mathrm{a}$ & $86 a$ & $84 a$ & $98 \mathrm{a}$ & $\hat{\mathrm{Y}}=75.77542+0.1688^{*} \mathrm{~N}$ & 0.84 \\
\hline
\end{tabular}


Rocha, Carvalho, Oliveira, Moraes, Santos Characterization of vegetative and reproductive tillerss...

15

30

$\begin{array}{llll}27 a & 51 a & 59 a & 37 b \\ 37 a & 56 a & 70 a & 75 a\end{array}$

$$
\hat{\mathrm{Y}}=26.69+0.9304^{*} \mathrm{~N}-0.007 * \mathrm{~N}^{2}
$$

$\hat{\mathrm{Y}}=40.210+0.3199 * \mathrm{~N}$

For each characteristic, means followed by the same letter in the column do not differ $(\mathrm{P}>0.10)$ by the t-test; * Significant by t-test $(\mathrm{P}<0.05)$.

The weight of the vegetative tillers was higher $(\mathrm{P}=0,0100)$ in the 30 cm stockpiled pasture compared to the $15 \mathrm{~cm}$, when the pasture was fertilized with 0 and $40 \mathrm{~kg} \mathrm{ha}^{-1}$ of $\mathrm{N}$ (Table 6). Probably, competition for light ensues between the tillers at the height of $30 \mathrm{~cm}$, which caused the stem to lengthen and the weight of the tiller to increase. However, when the pasture was fertilized with 80 and $120 \mathrm{~kg} \mathrm{ha}^{-1}$ of $\mathrm{N}$ (high doses), there were no differences in the weight of the vegetative tillers between the initial heights of the pastures (Table 6). This possibly occurred because the higher doses of nitrogen significantly increased the number of cells in the process of division (SKINNER \& NELSON, 1995), which consequently stimulated the high growth of tillers.

Table 6. Weight of vegetative and reproductive tillers in Marandu grass pastures managed with varying heights and nitrogen doses at the beginning of the stockpiling period

\begin{tabular}{|c|c|c|c|c|c|c|}
\hline \multirow{2}{*}{ height $(\mathrm{cm})$} & \multicolumn{4}{|c|}{ Nitrogen dose $\left(\mathrm{kg} \mathrm{ha}^{-1}\right)$} & \multirow{2}{*}{ Equation } & \multirow{2}{*}{$\mathrm{R}^{2}$} \\
\hline & 0 & 40 & 80 & 120 & & \\
\hline & \multicolumn{6}{|c|}{ Vegetative tiller (mg) } \\
\hline 15 & $549 \mathrm{~b}$ & $746 \mathrm{~b}$ & $910 \mathrm{a}$ & $1060 \mathrm{a}$ & $\hat{\mathrm{Y}}=575.3712+4.5929 * \mathrm{~N}$ & 0.91 \\
\hline \multirow[t]{2}{*}{30} & $778 \mathrm{a}$ & $1113 a$ & $1049 \mathrm{a}$ & $1133 a$ & $\hat{\mathrm{Y}}=854.5412+2.1548 * \mathrm{~N}$ & 0.43 \\
\hline & \multicolumn{6}{|c|}{ Reproductive tiller (mg) } \\
\hline 15 & $1033 a$ & $1408 \mathrm{a}$ & $1506 \mathrm{a}$ & $1309 b$ & $\bar{Y}=1314$ & - \\
\hline 30 & $1345 \mathrm{a}$ & $1862 \mathrm{a}$ & $2065 a$ & $2074 \mathrm{a}$ & $\hat{\mathrm{Y}}=1478.3140+5.9728^{*} \mathrm{~N}$ & 0.81 \\
\hline
\end{tabular}

For each characteristic, means followed by the same letter in the column do not differ $(\mathrm{P}>0.10)$ by the t-test; * Significant by t-test $(\mathrm{P}<0.05)$.

Nitrogen fertilization influenced positively and linearly $(\mathrm{P}=0,0064)$ the weight of vegetative tillers in 15 and $30-\mathrm{cm}$ stockpiled pastures, as well 
Rocha, Carvalho, Oliveira, Moraes, Santos Characterization of vegetative and reproductive tillerss...

as the weight of reproductive tillers in $30-\mathrm{cm}$ stockpiled pastures (Table 6). This was because $\mathrm{N}$ stimulates the growth of grasses.

When competition for light is small, i.e., when the pastures are lower, there are more small tillers. In higher pastures, the population density is lower for heavier tillers (SBRISSIA \& SILVA, 2008). As such, an inverse relationship between the number and weight of the vegetative tillers was expected for the $15 \mathrm{~cm}$ stockpiled pasture, which did not occur (Figure 1A). This effect is probably because nitrogen simultaneously stimulated tillering and tiller growth. This, in turn, may have been the result of less competition for light within the deferred pasture with lower initial height.

Figure 1. Relationship between the number and weight of vegetative tillers in Marandu grass pastures with $15 \mathrm{~cm}(\mathrm{~A})$ or $30 \mathrm{~cm}$ (B) at the beginning of the stockpiling period.
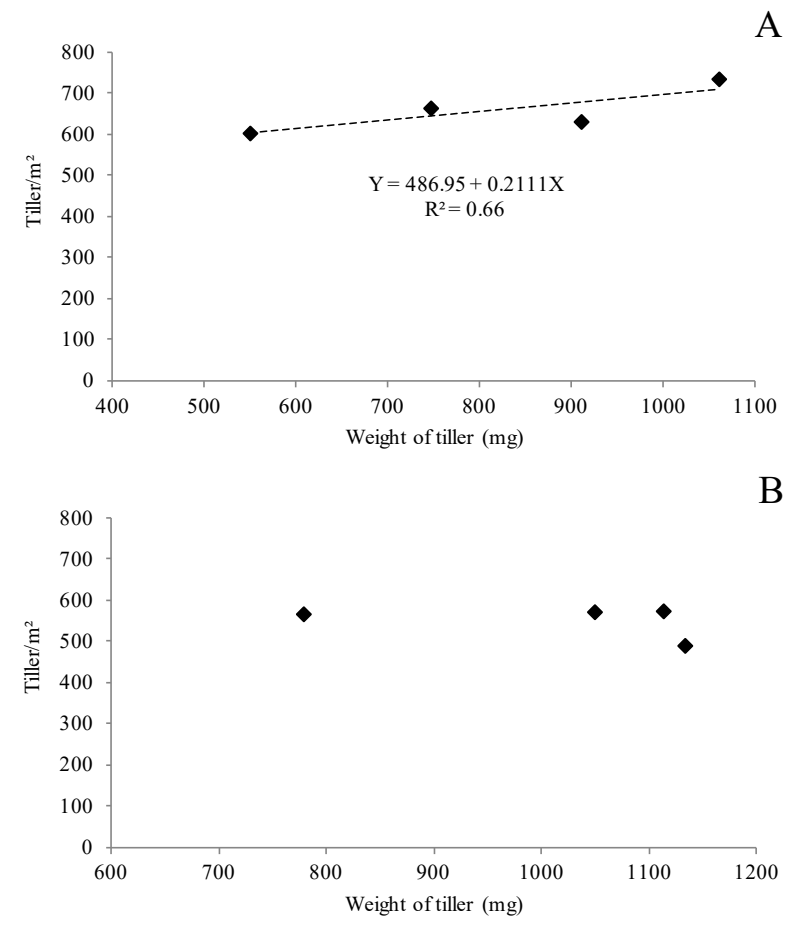

In contrast, there was no relationship between the number and the weight of vegetative tillers in the highest pasture at the beginning of the deferral period $(30 \mathrm{~cm})$ (Figure $1 \mathrm{~B})$. In this pasture, the number of tillers did 
not increase with the weight of the tiller probably because of the more shaded environment inside the highest deferred canopy, which inhibits tillering.

\section{Conclusion}

The pasture of Urochloa. brizantha cv. Marandu fertilized with nitrogen can be managed with $15 \mathrm{~cm}$ at the beginning of the stockpiling period to increase the number of vegetative tillers. It is not recommended to use doses above $80 \mathrm{~kg} \mathrm{ha}^{-1}$ of $\mathrm{N}$ at the beginning of the pasture stockpiling period with $U$. brizantha cv. Marandu to avoid impairing the morphological characteristics of the tillers.

\section{Caracterização de perfilhos vegetativos e reprodutivos como base para recomendar alturas e doses de nitrogênio para o diferimento do capim- marandu}

Resumo: Objetivou-se determinar a altura e a dose de nitrogênio no início do período de diferimento adequados para o diferimento da Urochloa brizantha cv. Marandu (capim-marandu). Duas alturas do pasto (15 e 30 $\mathrm{cm})$ e quatro doses de nitrogênio $\left(0,40,80\right.$ e $\left.120 \mathrm{~kg} \mathrm{ha}^{-1}\right)$ foram avaliadas em delineamento inteiramente aleatorizado, com três repetições em esquema fatorial $4 \times 2$. Houve aumento linear do número de perfilhos vegetativos com a aplicação de nitrogênio no pasto diferido com $15 \mathrm{~cm}$. Os comprimentos do colmo e das lâminas foliares dos perfilhos aumentaram linearmente com a aplicação de nitrogênio. $\mathrm{O}$ peso do perfilho vegetativo foi maior no pasto diferido com $30 \mathrm{~cm}$, comparado àquele com $15 \mathrm{~cm}$, quando o pasto foi adubado com 0 e $40 \mathrm{~kg}^{\text {ha }}{ }^{-1}$ de N. A adubação nitrogenada incrementou linearmente o peso dos perfilhos vegetativos nos pastos diferidos com $15 \mathrm{~cm}$, bem como o peso de perfilhos reprodutivos nos pastos diferidos com $30 \mathrm{~cm}$. Recomenda-se que o capim-marandu seja diferido com $15 \mathrm{~cm}$ e adubado com $80 \mathrm{~kg} \mathrm{ha}^{-1}$ de $\mathrm{N}$ no início do período de diferimento.

Palavras-chave: Adubação, Densidade Populacional, Estrutura, Urochloa brizantha, Período de diferimento. 
Rocha, Carvalho, Oliveira, Moraes, Santos Characterization of vegetative and reproductive tillerss...

\section{References}

AlVARES, C. A.; STAPE, J. L.; SENTElHAS, P. C.; GONÇALVES, J. L. M.; SPAROVEK, G. Köppen's climate classification map for Brazil. Meteorologische Zeitschrift, $\quad$ v. 22 , n. 6, p. 711-728, 2013. https://doi.org/10.1127/0941$\underline{2948 / 2013 / 0507}$

AMORIM, P. L.; FONSECA, D. M.; SANTOS, M. E.R.; PIMENTEL, R. M.; RODRIGUES, J. P. P.; ChIZZOTTI, F. H. M.; VITOR, C. G. Beef cattle performance on signal grass pastures deferred and fertilized with nitrogen. Arquivo brasileiro de medicina veterinária e zootecnia, v. 71, p. 1395-1402, 2019. https://doi.org/10.1590/1678-4162-10205

PEREIRA, L. E. T.; PAIVA, A. J.; GUARDA, V. DEL'ÁlAMO.; PEREIRA, P. M.; CAMINHA, F. O.; DA SILVA, S. C. Herbage utilisation efficiency of continuously stocked marandu palisade grass subjected to nitrogen fertilisation. Scientia Agricola, v. 72, p. 114-123, 2015. https://doi.org/10.1590/0103-9016-2014-0013

PEREIRA, V. V.; FONSECA, D. M.; MARTUSCELLO, J. A.; BRAZ, T. G. S.; SANTOS, M.V. CECON; P. R. Características morfogênicas e estruturais de capimmombaça em três densidades de cultivo adubado com nitrogênio. Revista Brasileira de Zootecnia, v. 40, p. 12, p. 2681-2689, 2011. DOI: https://doi.org/10.1590/S1516$\underline{35982011001200010}$

SANTOS, M. E. R.; OLIVEIRA, D. D.; FERNANDES, F. H. O.; NOGUEIRA, H. C. R.; CARVAlho, A. N.; BORGES, G. S.; BORGES; B. G. Tillering and tillers characterization of the deferred nitrogen fertilized marandu palisadegrass. Semina: Ciências Agrárias, v. 41, p. 621-632, 2020. http://dx.doi.org/10.5433/1679$\underline{0359.2020 \mathrm{v} 41 \mathrm{n} 2 \mathrm{p} 621}$

SBRISSIA, A. F; SILVA, S. C. Compensação tamanho/densidade populacional de perfilhos em pastos de capim-marandu. Revista Brasileira de Zootecnia, v. 37, n. 1, p. 35-47, 2008. DOI: http://dx.doi.org/10.1590/S1516-35982008000100005. 
Rocha, Carvalho, Oliveira, Moraes, Santos Characterization of vegetative and reproductive tillerss...

SKINNER, R. H.; NELSON, C. J. Elongation of the grass leaf and its relationship to the phyllochron. Crop Science, v. 35, n. 1, p. 4-10, 1995. DOI: https://doi.org/10.2135/cropsci1995.0011183X003 500010002x

SOUZA, B. M. L.; VILELA, H. H.; SANTOS, A. L.; SANTOS, M. E. R.; JÚNIOR, D.N.; ASSIS, C. Z.; FARIA, B. D.; ROCHA, G. O. Piata palisadegrass deferred in the fall: effects of initial height and nitrogen in the sward structure. Revista Brasileira de Zootecnia, v. 41, n. 5, p. 1134-1139, 2012. http://dx.doi.org/10.1590/S1516-35982012000500008 